\title{
An Empirical Research on the Evaluation Index Regarding the Service Quality of Agricultural Information Websites in China
}

\author{
Liyong Liu, Xiaoqing Yuan, and Daoliang Li* \\ College of Information and Electrical Engineering, China Agricultural University, \\ 17 Tsinghua East Road, P.O. Box 121, Beijing, 100083, P.R. China \\ li_daoliang@yaohoo.com
}

\begin{abstract}
Agricultural information website, which takes the mission of providing valid information for the expansive agricultural information demanders, is an important carrier for the state to enact its strategy of agriculture informatization. This paper establishes a set of evaluation measures regarding the service quality of agricultural information websites by setting up the index system of agricultural information websites, evaluates comprehensively agricultural information websites in the following four respects: the range of content, the operation, the benefits and the costs, and finally conducts an empirical research on 13 agricultural information websites in China to test and justify these measures.
\end{abstract}

Keywords: agricultural information website, information service, evaluation, index system.

\section{Introduction}

According to Gu Shen and An Baojun (2005), an agricultural information website should have agriculture industry as its main content; or both its target client and its main content or service involve agriculture industry. The website itself should at least meet one of these three requirements: (1) a website with independent domain and host server; (2) an independent website using webhost if without independent domain; (3) a website with virtual directory and independent complete information system if without independent domain or host server (Hu Dehua, Wang Jinhua, 2007).

\section{The Evaluation Index System}

\subsection{Constructing Evaluation Items}

Constructing evaluation items lays the basis for designing the evaluation index system of agricultural information websites. In accordance with the characteristics of agriculture websites, by breaking down the evaluation aims, four first-class evaluation

Corresponding author. Tel.: +86-10-62736764; Fax: +86-10-62737741. 
indexes can be established: the range of content, the operation, the benefits and the costs (Jia and Zhao, 2003); then sixteen second-class indexes can be established, such as the practicability, comprehensiveness, the accuracy, etc.; and finally thirty third-class indexes, such as satisfying the real demand for agricultural information (Li, 2008), targeting recipients, click rate, etc.

\subsection{Distributing the Weight of Indexes}

Among the first-class indexes, the range of content should be considered as the primary factor during the evaluation process, and the operation should be the second one. The benefits should be the third one due to the effectiveness and development consideration while evaluating the quality of websites. In addition, because of the development cost issue of websites, the cost should be regarded as the fourth factor. The weight of both the first-class indexes and the second-class indexes is decided through expert evaluating method and the results are shown in the table 1:

Table 1. The content and weight of first-class and second-class indexes

\begin{tabular}{|c|c|c|c|}
\hline First-class & Second-class & \begin{tabular}{|l|} 
Third-class \\
\end{tabular} & Weight \\
\hline \multirow{5}{*}{$\begin{array}{c}\text { The range of } \\
\text { content } \\
(0.4)\end{array}$} & Practicability 0.3 & $\begin{array}{l}\text { Satisfying the real demand for } \\
\text { agricultural information } \\
\text { Targeting recipients } \\
\text { Effectiveness level }\end{array}$ & $\begin{array}{l}0.5 \\
0.3 \\
0.2\end{array}$ \\
\hline & $\begin{array}{l}\text { Comprehensiveness } \\
0.2\end{array}$ & $\begin{array}{l}\text { Variety of agricultural information } \\
\text { Depth of agricultural information } \\
\text { Availability of original document }\end{array}$ & $\begin{array}{l}0.5 \\
0.35 \\
0.15\end{array}$ \\
\hline & Accuracy 0.25 & $\begin{array}{l}\text { Objectivity } \\
\text { Information standards }\end{array}$ & $\begin{array}{l}0.6 \\
0.4 \\
\end{array}$ \\
\hline & Authority 0.05 & $\begin{array}{l}\text { Reliability } \\
\text { Reputation of information provid- } \\
\text { ers }\end{array}$ & 0.6 \\
\hline & $\begin{array}{l}\text { Timeliness } 0.05 \\
\text { Specificity } 0.05\end{array}$ & $\begin{array}{l}\text { The longest update cycle } \\
\text { distinctiveness }\end{array}$ & $\begin{array}{l}1.0 \\
1.0\end{array}$ \\
\hline \multirow{6}{*}{$\begin{array}{l}\text { The operation } \\
(0 . .3)\end{array}$} & Stability 0.1 & $\begin{array}{l}\text { Providing information stably } \\
\text { Opening speed of the website }\end{array}$ & $\begin{array}{l}0.6 \\
0.4 \\
\end{array}$ \\
\hline & Navigation design 0.3 & $\begin{array}{l}\text { Internal linkage } \\
\text { Relativity of the linked resource }\end{array}$ & $\begin{array}{l}0.55 \\
0.45\end{array}$ \\
\hline & $\begin{array}{l}\text { Resources } \\
\text { organization } 0.2\end{array}$ & $\begin{array}{l}\text { Categories in terms of agricultural } \\
\text { subjects } \\
\text { Balance of all kinds of agricultural } \\
\text { information resources }\end{array}$ & 0.5 \\
\hline & User interface 0.2 & $\begin{array}{l}\text { Menu design } \\
\text { User interface } \\
\text { User guide and help information }\end{array}$ & $\begin{array}{l}0.4 \\
0.35 \\
0.25 \\
\end{array}$ \\
\hline & Search function 0.15 & $\begin{array}{l}\text { Search method } \\
\text { Search speed } \\
\text { Search range }\end{array}$ & $\begin{array}{l}0.4 \\
0.25 \\
0.35 \\
\end{array}$ \\
\hline & Connectivity 0.15 & $\begin{array}{l}\text { Response speed } \\
\text { Download speed }\end{array}$ & $\begin{array}{l}0.5 \\
0.5\end{array}$ \\
\hline
\end{tabular}


Table 1. (continued)

\begin{tabular}{clll}
\hline The benefits & Interactivity 0.5 & Registration, forum & 1.0 \\
\cline { 2 - 4 }$(0.2)$ & Effectiveness 0.5 & (global) click rate & 1.0 \\
\cline { 2 - 4 } The costs & Technical support 0.5 & Software and hardware requirements & 1.0 \\
\cline { 3 - 4 }$(0.1)$ & Connection cost 0.5 & Connection fee & 1.0 \\
\hline
\end{tabular}

\subsection{Three Levels of Grading Standards}

Evaluation objects can be rated into four levels as A, B, C, and D, each level is given different score scale. Therefore the evaluation criteria of websites are refined greatly. As shown in table 2, such a method is simple and clear and easy to operate.

Table 2. Three levels of grading standards

\begin{tabular}{ccccc}
\hline Three levels of grading & A & B & C & D \\
\hline Score scale & $90-99$ & $70-89$ & $60-69$ & $40-59$ \\
\hline
\end{tabular}

\subsection{Grading Criteria of Evaluation Objects (Agriculture Websites)}

Criteria of preparing index system refers to grading requirements for defining evaluation indexes. The evaluation system is divided into four levels: A $(91.00-100.00)$, B (81.00 - 90.00), C (71.00 - 80.00), and D (40.00 - 70.00), the scale of each level will be determined, and the evaluation results will be calculated by corresponding mathematical formula.

\section{Evaluation Method}

\subsection{Mathematical Modeling of Evaluation Indexes}

The overall objective of evaluation can be embodied in evaluation indexes which include sub-objectives (major evaluation respects) and factors (evaluation items). The series of index sets constitute the evaluation index system. The mathematical relation of the overall evaluation objective, sub-objectives and evaluation factors, namely the structure of the evaluation index system, is illustrated by the DirectionalTree Graph as shown in Chart 1 (Zhou, 2006).

In Chart $1, \mathrm{Z}$ refers to the evaluation object, which is the ultimate question solved by the evaluation system; F refers to the range of content in the first-class indexes; $\mathrm{S}$ is the operation in the second-class indexes (The benefits and costs are left out since this chart in this article is only for the purpose of brief explanation). DirectionalTree can be 


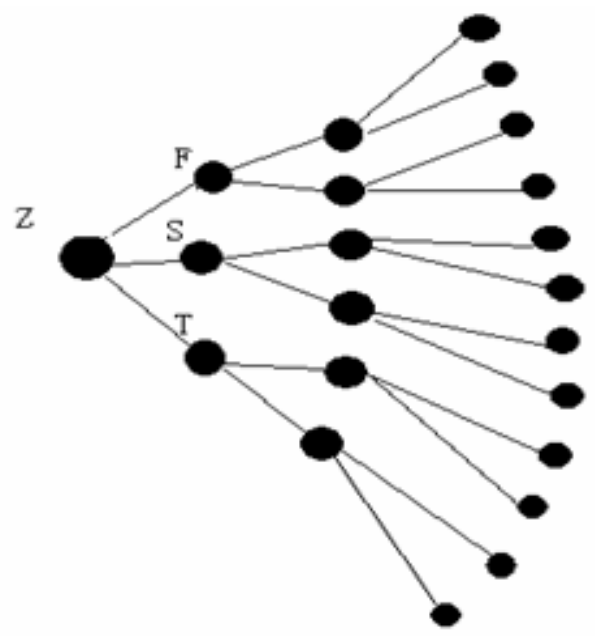

Chart 1. DirectionalTree Graph

mastered quickly and easily applied to concrete problems as it is a simple and manifest calculation model solving this kind of mathematical problems, its calculation process is easy to understand (Yang, Liu and Wang, 2009).

Taking DirectionalTree's advantages above, we analyzed and calculated agricultural information websites by this model, and got the final results.

\subsection{Analyzing and Calculating Process}

\subsubsection{Parameters Description}

$\mathrm{Z}$ : The overall index

$\mathrm{Z}_{\mathrm{i}}$ : first-class indexes $\left(\mathrm{Z}_{1}, \mathrm{Z}_{2}, \mathrm{Z}_{3}\right)$

$\mathrm{Z}_{\mathrm{ij}}$ : second-class indexes $\left(\mathrm{Z}_{11}-\mathrm{Z}_{1 \mathrm{n}}, \mathrm{Z}_{21}-\mathrm{Z}_{2 \mathrm{n}}, \mathrm{Z}_{31}-\mathrm{Z}_{3 \mathrm{n}}\right)$

$\mathrm{Z}_{\mathrm{ijk}}$ : third-class indexes $\left(\mathrm{Z}_{\mathrm{ij} 1}-\mathrm{Z}_{\mathrm{ijn}}, \mathrm{Z}_{\mathrm{ilk}}-\mathrm{Z}_{\mathrm{ink}}, \mathrm{Z}_{1 \mathrm{ik}}-\mathrm{Z}_{\mathrm{njk}}\right)$

$\alpha$ : Level correction factor $(\alpha \mathrm{A}: 0.0101, \alpha \mathrm{B}: 0.0112, \alpha \mathrm{C}: 0.0139, \alpha \mathrm{D}:$ 0.0145 )

NOTE: Considering the impact of the evaluator's subjective factors, we magnify the evaluation results properly and determine $\alpha$ in the following way: the full score of each level is presumed as a, then $\alpha=a /(a-1)-1$.

$\beta$ : weight of indexes on each level

\subsubsection{Calculation Process}

Step 1: $\mathrm{Z}_{\mathrm{ij}}=\sum \mathrm{Z}_{\mathrm{ijk}} \bullet \beta_{\mathrm{ijk}}$

Step 2: $\mathrm{Z}_{\mathrm{i}}=\sum \mathrm{Z}_{\mathrm{ij}} \bullet \beta_{\mathrm{ij}}=\sum \sum \mathrm{Z}_{\mathrm{ijk}} \bullet \beta_{\mathrm{ijk}} \beta_{\mathrm{ij}}$

Step 3: $\mathrm{Z}=\alpha \sum \mathrm{Z}_{\mathrm{i}} \bullet \beta_{\mathrm{i}}=\alpha \sum \sum \sum \mathrm{Z}_{\mathrm{ijk}} \bullet \beta_{\mathrm{ijk}} \beta_{\mathrm{ij}} \beta_{\mathrm{i}}$ 


\section{The Empirical Calculation of the Model}

13 agricultural information websites are selected for empirical research in this paper, which are: China Agriculture Web, Zhongshan Agricultural Information Web, China Livestock and Veterinary Web, China Forage Industry Information web, China Fruits web, China Agricultural Products Information Web, China Agricultural Products Information Window, Chengde Agricultural Information Web, China Plant Industry Information Web, Chinese Academy of Agricultural Sciences, Wanquan Agricultural Information Web, Zhengding Agricultural Information web and Shiji Rural Information Web. The scores and rank are listed in table 3, table 4 and table 5 as below.

Table 3. Scores of agricultural information websites based on second-class indexes

\begin{tabular}{|c|c|c|c|c|c|c|c|c|c|c|c|c|c|}
\hline \multirow{2}{*}{ Index } & \multicolumn{13}{|c|}{ Website } \\
\hline & 1 & 2 & 3 & 4 & 5 & 6 & 7 & 8 & 9 & 10 & 11 & 12 & 13 \\
\hline Practicability & 28.53 & 27.00 & 29.37 & 29.07 & 28.17 & 28.56 & 28.41 & 27.96 & 28.20 & 27.60 & 26.76 & 27.42 & 27.24 \\
\hline Comprehensiveness & 18.84 & 14.80 & 19.24 & 18.61 & 14.43 & 19.26 & 17.71 & 18.82 & 16.60 & 18.23 & 17.51 & 17.68 & 17.90 \\
\hline Accuracy & 24.10 & 21.25 & 24.05 & 24.30 & 21.25 & 26.65 & 22.75 & 22.80 & 23.75 & 23.45 & 24.45 & 22.95 & 21.30 \\
\hline Authority & 4.70 & 4.15 & 4.86 & 4.55 & 4.06 & 4.75 & 4.12 & 4.480 & 4.50 & 4.83 & 4.57 & 4.30 & 4.56 \\
\hline Timeliness & 4.90 & 4.45 & 4.95 & 4.95 & 2.95 & 4.95 & 4.90 & 4.950 & 4.25 & 4.25 & 4.75 & 4.75 & 4.70 \\
\hline Specificity & 4.75 & 3.25 & 4.45 & 2.95 & 3.15 & 4.90 & 4.50 & 4.450 & 4.75 & 4.40 & 4.65 & 4.70 & 4.65 \\
\hline Stability & 9.48 & 8.90 & 9.80 & 9.52 & 4.98 & 9.12 & 8.98 & 9.26 & 9.50 & 9.54 & 9.32 & 9.34 & 9.24 \\
\hline Navigation design & 28.34 & 27.83 & 28.97 & 28.91 & 26.76 & 26.67 & 22.50 & 27.69 & 24.52 & 27.83 & 26.57 & 26.25 & 27.83 \\
\hline Resources organization & 19.00 & 17.00 & 19.40 & 18.70 & 17.20 & 18.7 & 19.00 & 19.50 & 15.00 & 17.60 & 18.00 & 14.40 & 17.60 \\
\hline User interface & 19.60 & 17.21 & 17.36 & 12.52 & 14.02 & 19.31 & 19.50 & 17.07 & 17.69 & 17.50 & 16.00 & 17.37 & 17.90 \\
\hline Search function & 14.55 & 13.96 & 14.48 & 14.65 & 8.39 & 13.64 & 13.31 & 8.85 & 13.46 & 8.85 & 12.44 & 13.29 & 13.85 \\
\hline Connectivity & 13.65 & 11.63 & 12.53 & 12.38 & 7.88 & 11.03 & 8.78 & 11.85 & 10.50 & 13.88 & 11.03 & 13.80 & 13.80 \\
\hline Interactivity & 49.00 & 47.00 & 34.50 & 49.00 & 47.50 & 49.50 & 48.50 & 29.50 & 45.00 & 29.50 & 29.50 & 40.00 & 46.00 \\
\hline Effectiveness & 48.00 & 44.50 & 49.00 & 48.50 & 42.50 & 44.50 & 41.00 & 32.50 & 48.00 & 46.00 & 45.00 & 34.50 & 42.50 \\
\hline Technical support & 46.50 & 47.50 & 47.50 & 48.50 & 46.00 & 46.00 & 45.00 & 47.50 & 40.00 & 47.00 & 45.00 & 47.50 & 47.50 \\
\hline Connection cost & 47.00 & 47.50 & 47.50 & 48.50 & 47.50 & 46.00 & 45.00 & 47.50 & 45.00 & 47.50 & 45.00 & 47.00 & 47.50 \\
\hline
\end{tabular}

Note: 1 China Agriculture Web, 2 Zhongshan Agricultural Information Web, 3 China Livestock and Veterinary Web, 4 China Forage Industry Information web, 5 China Fruits Web, 6 China Agricultural Products Information Web, 7 China Agricultural Products Information Window, 8 Chengde Agricultural Information Web, 9 China Plant Industry Information Web, 10 Chinese Academy of Agricultural Sciences, 11 Wanquan Agricultural Information Web, 12 Zhengding Agricultural Information Web, 13 Shiji Rural Information Web. 
Table 4. Scores of agricultural information websites based on the first-class indexes

\begin{tabular}{|c|c|c|c|c|}
\hline \multirow[b]{2}{*}{ Website } & \multicolumn{4}{|c|}{ Index } \\
\hline & $\begin{array}{c}\text { The range of } \\
\text { content }\end{array}$ & $\begin{array}{c}\text { The } \\
\text { operation }\end{array}$ & $\begin{array}{c}\text { The } \\
\text { benefits }\end{array}$ & $\begin{array}{l}\text { The } \\
\text { costs }\end{array}$ \\
\hline Chsina Agriculture Web & 38.12 & 28.54 & 19.4 & 9.35 \\
\hline Zhongshan Agricultural Information Web & 33.52 & 26.29 & 18.3 & 9.5 \\
\hline China Livestock and Veterinary Web & 38.69 & 27.82 & 16.7 & 9.5 \\
\hline China Forage Industry Information Web & 37.58 & 26.15 & 19.5 & 9.65 \\
\hline China Fruits Web & 31.6 & 22.28 & 18 & 9.35 \\
\hline $\begin{array}{l}\text { China Agricultural Products Information } \\
\text { Web }\end{array}$ & 39.28 & 26.8 & 18.8 & 9.2 \\
\hline $\begin{array}{l}\text { China Agricultural Products Information } \\
\text { Window }\end{array}$ & 36.55 & 24.92 & 17.9 & 9 \\
\hline Chengde Agricultural Information Web & 37.09 & 25.49 & 12.4 & 9.5 \\
\hline China Plant Industry Information Web & 36.62 & 17.00 & 18.6 & 8.5 \\
\hline $\begin{array}{l}\text { Chinese Academy of Agricultural } \\
\text { Sciences }\end{array}$ & 36.92 & 25.7 & 15.1 & 9.45 \\
\hline Wanquan Agricultural Information Web & 36.81 & 25.23 & 14.9 & 9 \\
\hline Zhengding Agricultural Information Web & 36.46 & 25.53 & 14.9 & 9.45 \\
\hline Shiji rural Information Web & 35.72 & 27.29 & 17.7 & 9.5 \\
\hline
\end{tabular}

Table 5. Overall ranking of agricultural information websites

\begin{tabular}{|c|c|c|c|}
\hline Rank & Website & Score & Grade \\
\hline 1 & China Agriculture Web & 96.37 & A \\
\hline 2 & $\begin{array}{l}\text { China Agricultural Products Information } \\
\text { Web }\end{array}$ & 95.03 & A \\
\hline 3 & China Forage Industry Information Web & 94.67 & A \\
\hline 4 & China Plant Industry Information Web & 94.15 & A \\
\hline 5 & China Livestock and Veterinary Web & 93.64 & A \\
\hline 6 & Shiji Rural Information Web & 91.12 & A \\
\hline 7 & $\begin{array}{l}\text { China Agricultural Products Information } \\
\text { Window }\end{array}$ & 89.36 & $\mathrm{~B}$ \\
\hline 8 & Zhongshan Agricultural Information Web & 88.59 & B \\
\hline 9 & $\begin{array}{l}\text { Chinese Academy of Agricultural } \\
\text { Sciences }\end{array}$ & 88.14 & B \\
\hline 10 & Zhengding Agricultural Information Web & 87.31 & B \\
\hline 11 & Wanquan Agricultural Information Web & 86.9 & B \\
\hline 12 & Chengde Agricultural Information Web & 85.42 & B \\
\hline 13 & China Fruits Web & 82.13 & $\mathrm{~B}$ \\
\hline
\end{tabular}


It is demonstrated by Table 5 that six websites including China Agriculture Web, China Agricultural Products Information Web, China Forage Industry Information Web, China Plant Industry Web, China Livestock and Veterinary Web, and Shiji Rural Information Web all got high scores over 90 . Hence they can be classified into A-class agricultural information websites. Particularly, these six websites all have an outstanding performance in terms of the range of content, the operation and can be viewed as the model of rural information websites. However the other seven websites such as China Agricultural Information Window, Zhongshan Agricultural Information Web and Chengde Agricultural Information Web score less. Some specific respects of these websites remain to be improved although they meet the basic needs of rural information demanders.

In addition, scores and ranking based on each index are listed in table 6 , table 7 , table 8 and table 9 below.

Table 6. Scores and ranking based on the range of content

\begin{tabular}{clc}
\hline Ranking & \multicolumn{1}{c}{ Website } & Score \\
\hline 1 & China Agriculture Web & 28.54 \\
2 & China Plant Industry Information Web & 27.84 \\
3 & China Livestock and Veterinary Web & 27.82 \\
4 & Shiji Rural Information Web & 27.29 \\
5 & China Agricultural Products Information Web & 26.80 \\
6 & Zhongshan Agricultural Information Web & 26.29 \\
7 & China Forage Industry Information Web & 26.15 \\
8 & Chinese Academy of Agricultural Sciences & 25.70 \\
9 & Zhengding Agricultural Information Web & 25.53 \\
10 & Chengde Agricultural Information Web & 25.49 \\
11 & Wanquan Agricultural Information Web & 25.23 \\
12 & China Agricultural Products Information Web & 24.92 \\
13 & China Fruits Web & 22.28 \\
\hline
\end{tabular}

Table 7. Scores and ranking based on the operation

\begin{tabular}{clc}
\hline Ranking & \multicolumn{1}{c}{ Website } & Score \\
\hline 1 & China Agriculture Web & 28.54 \\
2 & China Plant Industry Information Web & 27.84 \\
3 & China Livestock and Veterinary Web & 27.82 \\
4 & Shiji Rural Information Web & 27.29 \\
5 & China Agricultural Products Information Web & 26.80 \\
6 & Zhongshan Agricultural Information Web & 26.29 \\
7 & China Forage Industry Information Web & 26.15 \\
\hline
\end{tabular}


Table 7. (continued)

\begin{tabular}{cll}
\hline 8 & Chinese Academy of Agricultural Sciences & 25.70 \\
9 & Zhengding Agricultural Information Web & 25.53 \\
10 & Chengde Agricultural Information Web & 25.49 \\
11 & Wanquan Agricultural Information Web & 25.23 \\
12 & China Agricultural Products Information Window & 24.92 \\
13 & China Fruits Web & 22.28 \\
\hline
\end{tabular}

Table 8. Scores and ranking based on the benefits

\begin{tabular}{clc}
\hline Ranking & \multicolumn{1}{c}{ Website } & Score \\
\hline 1 & China Forage Industry Information Web & 19.50 \\
2 & China Agriculture Web & 19.40 \\
3 & China Agricultural Products Information Web & 18.80 \\
4 & China Plant Industry Information Web & 18.60 \\
5 & Zhongshan Agricultural Information Web & 18.30 \\
6 & China Fruits Web & 18.00 \\
7 & China Agricultural Products Information Web & 17.90 \\
8 & Shiji Rural Information Web & 17.70 \\
9 & China Livestock and Veterinary Web & 16.70 \\
10 & Chinese Academy of Agricultural Sciences & 15.10 \\
11 & engding Agricultural Information Web & 14.90 \\
12 & Wanquan Agricultural Information Web & 14.90 \\
13 & Chengde Agricultural Information Web & 12.40 \\
\hline
\end{tabular}

Table 9. Scores and ranking based on the costs

\begin{tabular}{cll}
\hline \multirow{2}{*}{ Ranking } & \multicolumn{1}{c}{ Website } & Score \\
\hline 1 & China Forage Industry Information Web & 9.65 \\
2 & China Livestock and Veterinary Web & 9.50 \\
3 & Chengde Agricultural Information Web & 9.50 \\
4 & Shiji Agricultural Information Web & 9.50 \\
5 & 'hongshan Agricultural Information Web & 9.50 \\
6 & China Plant Industry Information Web & 9.45 \\
7 & Zhengding Agricultural Inforation Web & 9.45 \\
8 & Chinese Academy of Agricultural Sciences & 9.45 \\
9 & China Fruits Web & 9.35 \\
10 & China Agriculture Web & 9.35 \\
11 & China Agricultural Products Information Web & 9.2 \\
12 & China Agricultural Products Information Window & 9.00 \\
13 & Wanquan Agricultural Information Web & 9.00 \\
\hline
\end{tabular}


It can be interpreted from these tables that in terms of the range of content, all these websites score relatively equal and most of them is capable of providing real, accurate and comparatively extensive and deep agricultural information. This suggests that Chinese agricultural information websites' amount and depth of information are increasing annually.

In terms of the operation, each website performs well. For instance, China Agriculture Web, China Plant Industry Information Web and China Livestock and Veterinary Web have a reasonable navigation design, evenly distributed resources, friendly user interface and convenient function of search and download while China Livestock and Veterinary Web has a very good navigation design and users can retrieve information clearly as long as they login to the website.

As far as the benefits are concerned, users can easily judge which website does well or not since this index has a strong objectivity. For example, Chinese Academy of Agricultural Sciences doesn't score very due to its lacking of functions of registration, forum and etc. in spite of its favorable impression on users.

As for the costs, all of these websites have lower requirements for users' internet condition and the connection fee of each website is not high either. And these websites would benefit from these to expand their user scope.

\section{Conclusion}

The evaluation method for the service quality of agricultural information websites constructed by this research is a relative scientific and impartial method by establishing the evaluation principles and method and applying to 13 agricultural information websites in random. It does not look at a website only from a single respect nor roughly evaluate a website from all respects. On the contrary, it evaluates the quality of a website based on the most important 30 respects and furthermore it is simple and clear, easy to learn and use, and can be used by anyone on any condition to evaluate a website scientifically and objectively.

\section{References}

[1] Gu, S., An, B.J.: The Status Quo and Analysis of Agricultural Information Websites Construction in China. Agricultural Network Information (7) (2005)

[2] Hu, D.H., Wang, J.H.: The Evaluation of University Library Websites Based on Information Construction Theory. Information Science (2) (2007)

[3] Jia, S.G., Zhao, Y.J.: The Status Quo and Analysis of Agricultural Information Website Construction in China. Computer and Agriculture (9) (2003)

[4] Wang, X.L.: The Evaluation System of Professional Websites. Information Magazine (10) (2002)

[5] Zhou, H.: Constructing the Evaluation System on Information Resources of Medical Websites by Applying Mathematical Model. Medical Information Magazine (3) (2006)

[6] Yang, H.Y., Liu, J., Wang, C.Q.: The Application of AHP in the Evaluation of Agricultural Information Websites. Anhui Agricultural Science 37(28), 13940-13942 (2009)

[7] Li, D.L.: China's rural informatization development report 2007. China's agricultural science and technology publishing press (2007) 